\title{
Bacterial structures and ecosystem functions in glaciated floodplains: contemporary states and potential future shifts
}

\author{
Remo Freimann ${ }^{1,2}$, Helmut Bürgmann ${ }^{3}$, Stuart EG Findlay ${ }^{4}$ and Christopher T Robinson ${ }^{1}$ \\ ${ }^{1}$ Department of Aquatic Ecology, Eawag, Swiss Federal Institute of Aquatic Science and Technology, \\ Dübendorf, Switzerland; ${ }^{2}$ Institute of Molecular Health Sciences, ETH-Zürich, Switzerland; ${ }^{3}$ Eawag, \\ Swiss Federal Institute of Aquatic Science and Technology, Department of Surface Waters-Research and \\ Management, Kastanienbaum, Switzerland and ${ }^{4}$ Cary Institute of Ecosystem Studies, Millbrook, NY, USA
}

\begin{abstract}
Glaciated alpine floodplains are responding quickly to climate change through shrinking ice masses. Given the expected future changes in their physicochemical environment, we anticipated variable shifts in structure and ecosystem functioning of hyporheic microbial communities in proglacial alpine streams, depending on present community characteristics and landscape structures. We examined microbial structure and functioning during different hydrologic periods in glacial (kryal) streams and, as contrasting systems, groundwater-fed (krenal) streams. Three catchments were chosen to cover an array of landscape features, including interconnected lakes, differences in local geology and degree of deglaciation. Community structure was assessed by automated ribosomal intergenic spacer analysis and microbial function by potential enzyme activities. We found each catchment to contain a distinct bacterial community structure and different degrees of separation in structure and functioning that were linked to the physicochemical properties of the waters within each catchment. Bacterial communities showed high functional plasticity, although achieved by different strategies in each system. Typical kryal communities showed a strong linkage of structure and function that indicated a major prevalence of specialists, whereas krenal sediments were dominated by generalists. With the rapid retreat of glaciers and therefore altered ecohydrological characteristics, lotic microbial structure and functioning are likely to change substantially in proglacial floodplains in the future. The trajectory of these changes will vary depending on contemporary bacterial community characteristics and landscape structures that ultimately determine the sustainability of ecosystem functioning.
\end{abstract}

The ISME Journal (2013) 7, 2361-2373; doi:10.1038/ismej.2013.114; published online 11 July 2013

Subject Category: Microbial ecology and functional diversity of natural habitats

Keywords: glacier; biofilm; hyporheic sediment; stream; bacterial communities

\section{Introduction}

Heterotrophic bacteria are crucial in the functional ecology of aquatic ecosystems, being the driving force behind metabolic processes like respiration and productivity, nutrient cycling and fluxes, trophic links with secondary consumers and numerous biogeochemical processes (Edwards et al., 1990; Kirchman, 1994; Hall and Meyer, 1998; Acuna et al., 2008). The hyporheic zone and its heterotrophic components have an important role by integrating many of these ecosystem functions (EFs) at the interface between surface waters, groundwaters and

Correspondence: R Freimann, Institute of Molecular Health Sciences, Professorship of Genetics, HPL E22.1, Schafmattstrasse 22, Zurich 8093, Switzerland.

E-mail: remofreimann@gmail.com

Received 18 February 2013; revised 16 May 2013; accepted 7 June 2013; published online 11 July 2013 the riparian zone (Hendricks, 1993; Stanford and Ward, 1993; Findlay, 1995; Battin, 1999). Alpine aquatic systems are undergoing rapid change in response to glacier recession, thereby providing the opportunity to examine structural and functional responses of bacterial communities (see Milner et al., 2009) to potential changes in environmental conditions, especially in high elevation lotic systems.

Globally, alpine catchments are major sources of freshwater because of relatively high levels of precipitation, often stored as snow and ice in glaciers. This stored water is then released during warm periods as snow and glacial meltwaters. Groundwater-fed streams also are common in alpine catchments. Hence, the majority of running waters in glaciated alpine floodplains can be characterized as either glacier-meltwater-fed (kryal) or groundwater-fed (krenal) channels, or streams dominated by snowmelt (rhithral) during spring (Brown et al., 
2003). These different types of streams have distinct annual and diel discharge patterns (flow regimens), hydrological linkages and physicochemical characteristics (Ward, 1994; Tockner et al., 1997; Brown and Fuge, 1998; Smith et al., 2001). Krenal systems, for example, are less influenced by discharge fluctuations, whereas kryal systems show high discharge during summer ablation and an increasing influence of groundwater towards winter (Brown and Fuge, 1998). Owing to these different dynamics in biogeochemical and physical characteristics, diverse habitat patches are created.

Regional climate models predict an increase in mean temperature in European Alpine regions and more rapid glacial melting (Horton et al., 2006; Zemp et al., 2006; IPCC, 2007). Krenal systems will likely become more common as glaciers retreat and precipitation patterns change, for example, projections suggest that precipitation periods will shift from reduced precipitation in summer towards increased precipitation in late winter (Swiss Climate Change Scenarios CH2011, 2011). Landscape heterogeneity, as influenced by glaciers, will be reduced and a consequent shift in flow source and regimen towards more krenal-regulated systems is expected. This shift in water source will have a large effect on the physicochemical and ecological state of alpine lotic systems (Hall and Fagre, 2003). For instance, the quality, quantity and timing of resources, such as organic matter (OM) and nutrient inputs, are highly affected by shifts in environmental and hydrological conditions, and will likely influence heterotrophic bacteria assemblages and their ecological services or functioning (Boyer et al., 1997; Findlay and Sinsabaugh, 1999; Horton et al., 2006).

Although the above-mentioned changes in environmental conditions will potentially affect EFs mediated by bacterial assemblages, the underlying mechanisms and future trajectories of EF are poorly understood. This is mainly because altered EF can be either linked to changes in bacterial community composition (BCC), single-cell metabolism or changes in total cell numbers (Comte and Del Giorgio, 2011). Which mechanism has the important role in potential future shifts in EF may depend on present bacterial community characteristics (i.e. apparent functional redundancy and plasticity, domination of generalists vs specialists) and the strength of changes in environmental variables (Allison and Martiny, 2008). In this study, our main objective was to characterize BCC and EF (assessed as potential enzymatic activity) within hyporheic sediments in glaciated alpine floodplains in relation to potential environmental drivers and their spatiotemporal dynamics. We examined streams at different spatial scales (within and between catchments) covering a diverse set of landscape features (such as glaciers and lakes) and different degrees of spatial connectivity. In particular, we chose kryal and krenal streams within three different alpine catchments, focusing on spatial and temporal differences in physicochemical and microbial characteristics of the streams. Because of the more pronounced heterogeneity (spatial and temporal) within kryal systems, we hypothesized that microbial communities will either show strong resistance and steadystate characteristics because of high functional plasticity or a high degree of community turnover because of competing species that are adapted to a specific temporary condition. We interpret the results in the context of current landscape structures (degree of deglaciation, geological background and stream network structure) and discuss the findings in the light of potential future trajectories of BCC and linked EF because of environmental change and contemporary BCC characteristics. This study provides new information on the potential shifts in bacterial communities and their ecosystem functioning within alpine catchments in relation to expected scenarios of changing alpine water regimens and landscape structures resulting from global change.

\section{Materials and methods}

Study floodplains

Geographical location, geological characterization and hydrological conditions in the three study sites, Val Roseg (VR), Loetschental (L) and Macun (M), are

Table 1 Characteristics of the three alpine catchments

\begin{tabular}{lccc}
\hline Catchment & Val Roseg & Loetschental & Macun \\
\hline Coordinates & $9^{\circ} 53^{\prime} 53^{\prime \prime} \mathrm{E}, 46^{\circ} 29^{\prime} 24^{\prime \prime} \mathrm{N}$ & $07^{\circ} 49^{\prime} 03^{\prime \prime} \mathrm{E}, 46^{\circ} 25^{\prime} 08^{\prime \prime} \mathrm{N}$ & $10^{\circ} 07^{\prime} 31^{\prime \prime} \mathrm{E}, 46^{\circ} 43^{\prime} 51^{\prime \prime} \mathrm{N}$ \\
Altitude (m a.s.l.) & $1766-4049$ & $1375-3200$ & $2616-3046$ \\
Catchment area $\left(\mathrm{km}^{2}\right),(\%$ glaciated) & $66.5(30.1)$ & $77.8(36.5)$ & $3.6(18.8)^{\mathrm{a}}$ \\
Annual precipitation (m) & 1.6 & 1.1 & 0.9 \\
Mean discharge $\left(\mathrm{m}^{3} \mathrm{~s}^{-1}\right)$ & 28.5 & 47.2 & $\mathrm{ND}$ \\
Mean water temperature of main channel & $3.6(1-12)$ & $4(0.1-10.9)$ & $2.9(0.1-19.2)$ \\
$\left({ }^{\circ} \mathrm{C}\right)$ (range) & Crystalline bedrock, diorite, & Crystalline bedrock, amphibo- \\
Geology, dominating rock types & granite & lite, gneiss & Crystalline bedrock, \\
& orthogneiss
\end{tabular}

Abbreviation: ND, no data.

${ }^{\text {a Rock glaciers. }}$ 
given in Table 1 (sources: Labhart, 1998; Malard et al., 1999; Robinson and Kawecka, 2005; Schmidt et al., 2009; BAFU, 2010).

The waters of the Roseg and Loetschental catchments are partly fed by valley glaciers, which have retreated continuously over the past century (Maisch, 1988; Tockner et al., 1997, 2002; Malard et al., 2000). Permanently flowing first-order tributaries contribute groundwater and snowmelt to kryal main channels, which have peak flows during spring and summer (Malard et al., 2000). Loetschental study sites are divided between two subcatchments (Figure 1). The Macun Lakes region is a high alpine cirque. The catchment is divided into a southern and northern basin that differs in their water source (Robinson and Matthaei, 2007). The northern basin is mainly groundwater and snowmelt fed, whereas the southern basin is fed mostly by rock glaciers. All catchments experience contraction of surface channels in winter (Robinson and Matthaei, 2007).

\section{Sediment sampling}

Hyporheic sediment samples for analysis of bacteria were collected from selected sites in all three catchments during July/August (A) and October (O) 2008. The Val Roseg and Loetschental catchments were also sampled in June (J) 2009. A total of 45 sites were sampled: 10 kryal sites and 8 krenal sites in the Val Roseg (VR1-VR18), 4 kryal sites and 6 krenal sites in Loetschental (L1-L10) and 6 kryal sites and 11 krenal sites in the Macun catchment (M1-M17) (Figure 1). Water systems were distinguished based on previous studies (Tockner et al., 1997; Robinson et al., 2007) or determined by geographical position relative to the glaciers. Thirteen out of 118 potential samples were either not sampled or included in the data analysis: 5 sites that were dry in Val Roseg and Loetschental in October (VR3, VR17, L2, L3 and L8), Roseg site VR11 in June because of potential contamination and Macun samples M1, M5, M11, M13, M15, M16, M17 that were snow-covered in October and thus inaccessible. Sample sites were chosen owing to their relative position along the flow path (longitudinal and lateral) and owing to their position in context of landscape structures (lakes and glaciers).

For each sediment sample, the upper $\sim 10 \mathrm{~cm}$ of streambed sediment was removed to avoid sampling bacteria associated with benthic biofilms. Sediment samples were then taken to a depth of ca. $20 \mathrm{~cm}$, being sieved through an 8-mm mesh sieve (Retsch $\mathrm{GmbH}$, Haan, Germany). All samples were transported in a cooling box to the laboratory, where samples for DNA extraction and enzyme assays were frozen at $-20^{\circ} \mathrm{C}$. Fixation for microscopic analysis was performed within $12 \mathrm{~h}$ of sampling (see below).
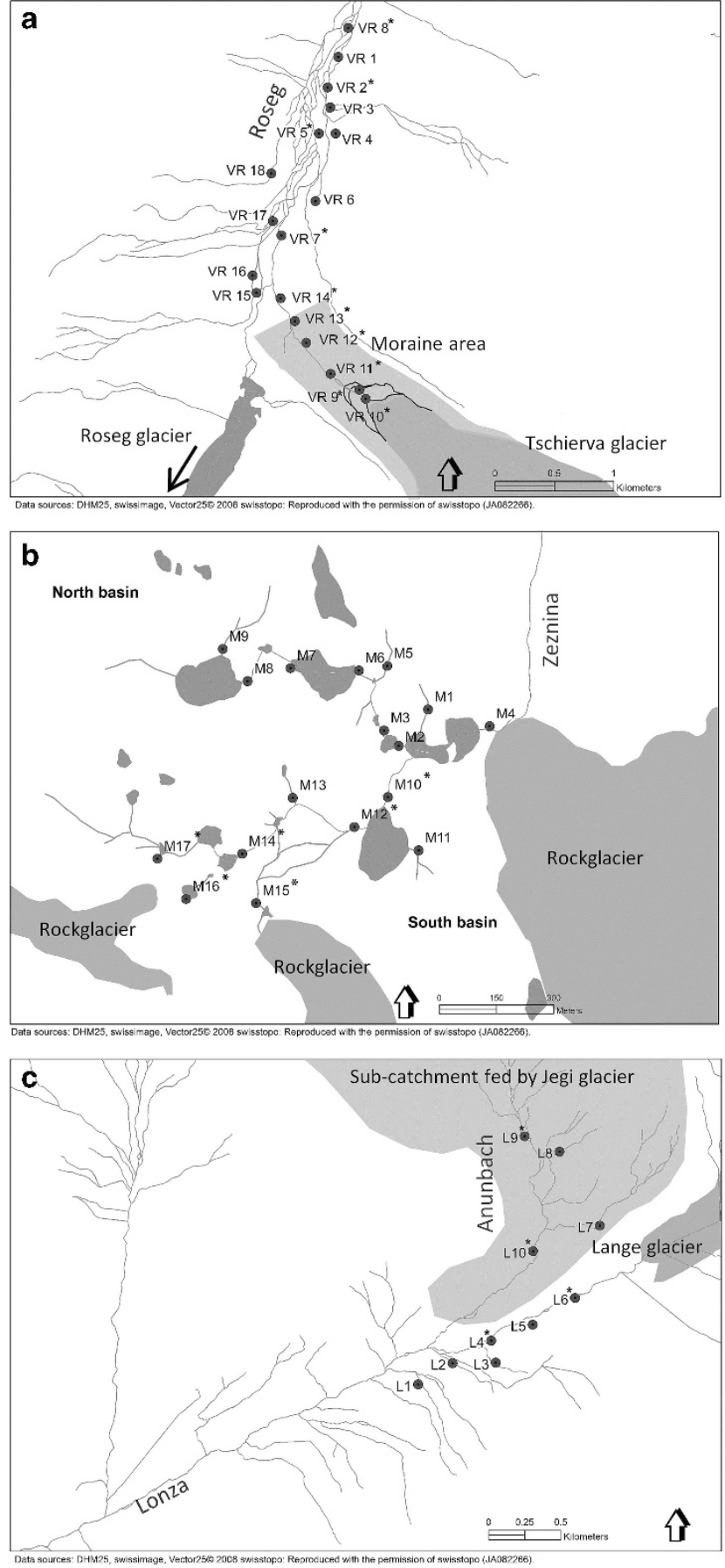

Figure 1 Map of the study catchments and location of sampling sites in (a) Val Roseg, (b) Macun, (c) Loetschental. Kryal sites have an asterisk. Streams are delineated in gray. Lakes and glaciers are depicted as dark gray and gray areas, respectively. Light gray indicates the subcatchment in Loetschental and the moraine area in Val Roseg.

Physicochemical water variables

Specific conductivity $\left(\mu \mathrm{S} \mathrm{cm}^{-1}\right.$ at $\left.20^{\circ} \mathrm{C}\right)$ and temperature were measured in the field with a conductivity meter (LF323; WTW, Weilheim, Germany). Surface water samples (1 L) were collected and transported in a cooling box to the laboratory. The 
water was then filtered through preashed glass fiber filters (GF/F, Whatmann) and the filtrate analyzed for dissolved OM, particulate organic carbon (POC), total inorganic carbon (TIC), ammonium $\left(\mathrm{NH}_{4}-\mathrm{N}\right)$, nitrite $\left(\mathrm{NO}_{2}-\mathrm{N}\right)$, nitrate $\left(\mathrm{NO}_{3}-\mathrm{N}\right)$, dissolved organic nitrogen, particulate organic nitrogen, phosphate $\left(\mathrm{PO}_{4}-\mathrm{P}\right)$, dissolved phosphorus and particulate phosphorus (PP) according to standard protocols detailed in Tockner et al. (1997). We chose to sample surface water instead of pore water as most sites showed relatively coarse substrate (see sediment sorting coefficients below and in the Supplementary Material); thus, a strong similarity of surface and subsurface waters within the upper sediment layers was likely. Results of the most important physicochemical parameters are presented in Figure 2 and further discussed in the Supplementary Information.

\section{Sediment characteristics}

Subsamples of the collected sediments were air-dried at $50^{\circ} \mathrm{C}$ and then used to measure $\mathrm{pH}$ as described in Schofield and Taylor (1955). Total sediment $\mathrm{OM}$ was determined as ash-free dry mass by combusting the samples at $450{ }^{\circ} \mathrm{C}$ for $4 \mathrm{~h}$. The remaining material was then used to determine
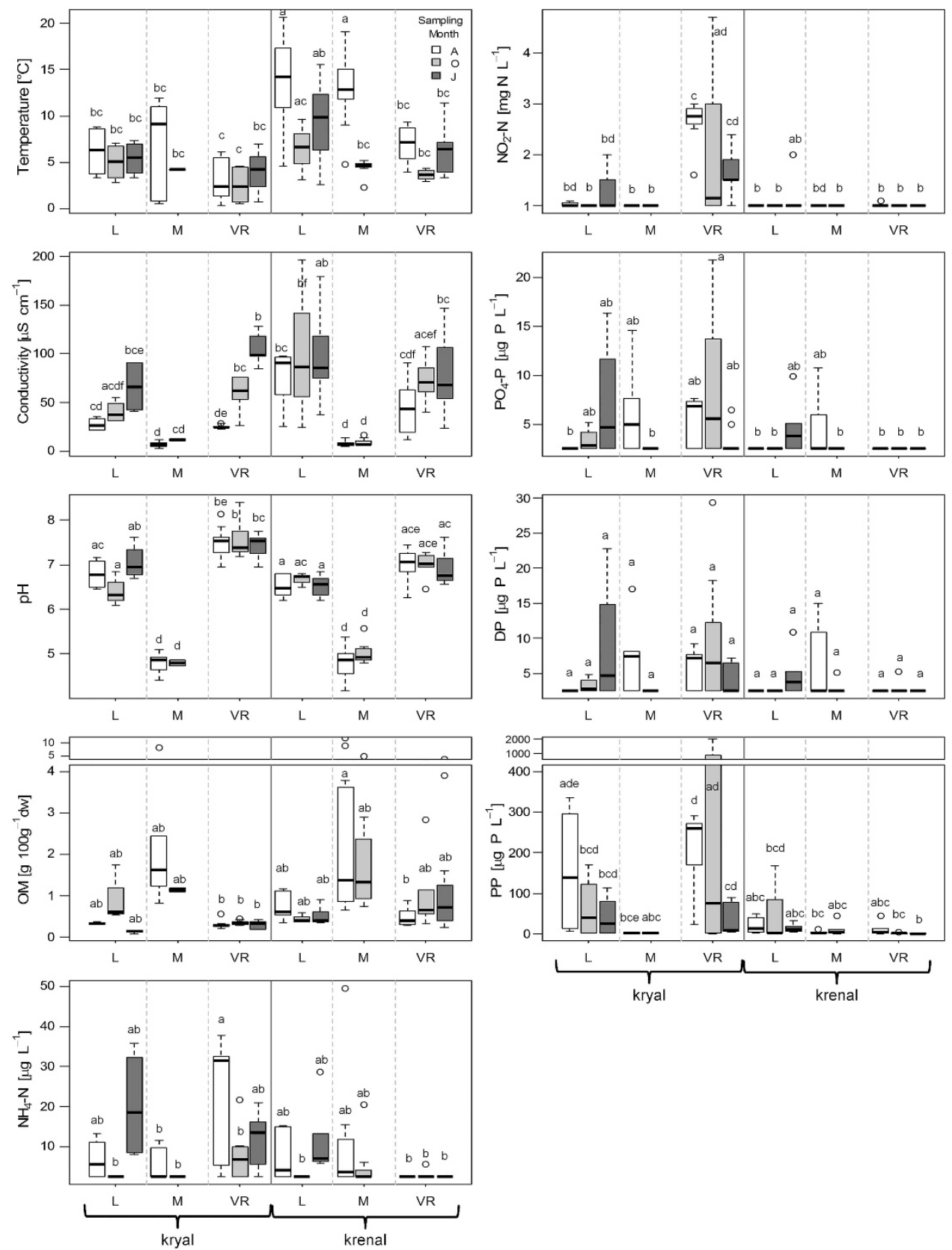

Figure 2 Boxplots of environmental variables. Whiskers indicate $1.5 \times$ interquartile range. Groups are split by water source (brackets), catchments and sampling dates. Letters show significant differences based on Tukey's honestly significant difference $(P<0.05)$. 
grain size distribution using a sieving machine (Retsch GmbH, Haan, Germany) at mesh sizes of $6.3,2.0,1.0,0.5,0.25,0.125$ and $0.063 \mathrm{~mm}$. The size distribution was analyzed using the GRADISTAT software (Simon and Blott, 2001) to give the D90/D10 sorting coefficient as a measure of sediment interpacking.

\section{Bacterial total cell numbers}

A 0.5-ml aliquot of collected sediment was suspended in 1.11-ml paraformaldehyde ( $2 \%$, final concentration) in an Eppendorf tube and fixed for $24 \mathrm{~h}$ at $4{ }^{\circ} \mathrm{C}$ followed by three washing steps with $1 \times$ phosphate-buffered saline and 5 min centrifugation at $10000 \mathrm{~g}$ between washing steps. Samples were then stored at $-20^{\circ} \mathrm{C}$ in a $1: 1$ mix of phosphate-buffered saline/ethanol until further processing (Pernthaler et al., 2001). Cell detachment was carried out by sonication (Branson Digital Sonifier 250, Danbury, CT, USA; 5-mm tapered microtip, actual output of $20 \mathrm{~W}, 30 \mathrm{~s}$ ). The homogenate served as a template for filtration-based counting of 4',6-diamidino-2-phenylindole- (SigmaAldrich Co., St Louis, MO, USA) stained cells (Porter and Feig, 1980). Photographs taken with an epifluorescence microscope (Leica Microsystem, Heerbrugg, Switzerland; DMI6000b) were analyzed with the CellC software (CellC Cell Counting, Tampere, Finland) (Selinummi et al., 2005) or counted manually in case of high background fluorescence. Detailed information for this and the following sections of Materials and methods, statistical analysis and an in-depth discussion on specific results are available in the Supplementary Material.

\section{Enzyme assays}

Eight different enzymes were tested for their activity using methylumbelliferone-labeled substrate analogs. They were chosen based on their potential role in bacterial metabolism. (Table 2, Vihinen and Mäntsälä, 1989; Sinsabaugh et al., 1991; Arpigny and Jaeger, 1999; Makoi and Ndakidemi, 2008; Sinsabaugh et al., 2008). Fluorometric enzyme assays were performed under standardized conditions as described before (Findlay et al., 2001). All values were corrected for quenching and potential autofluorescence, that is, because of the presence of small mineral particles, and subsequently standardized to OM. The activity of single enzymes is presented in Figure 3.

\section{Bacterial community fingerprinting}

BCC was assessed by automated ribosomal intergenic spacer analysis (ARISA). Samples ( $\sim 2$ g) were extracted using the PowerSoil DNA isolation Kit (MoBio, Carlsbad, CA, USA) following the manufacturer's instructions. DNA was amplified using the fluorescein (6-FAM)-labeled universal forward primer 1406f-6FAM and the bacteria-specific reverse primer 23Sr (Yannarell et al., 2003). ARISA fragment analysis was performed as described in Bürgmann et al. (2011).

\section{Data analysis}

All statistical analyses were carried out using the vegan, relaimpo and mgcr packages in $\mathrm{R}$ (Grömping, 2006; Wood, 2006; Oksanen et al., 2011; R Development Core Team, 2012).

Community fingerprinting results and enzymatic activities were analyzed with redundancy analysis (RDA) based on forward selected environmental explanatory variables. RDA-based variation partitioning on ARISA and enzyme activity data were performed to evaluate the influence of chemical and physical (temperature and D90D10) variables on BCC and EF. Unique fractions of RDA were tested by analysis of variance (ANOVA)-like permutation tests (Peres-Neto et al., 2006; Blanchet et al., 2008). A Mantel test was performed to assess the linkage between BCC and EF (Mantel, 1967).

Permutational multivariate ANOVA (PERMANOVA) was used to assess the influence of water source,

Table 2 Enzymes analyzed in this study, substrate used for assays and their biogeochemical functions

\begin{tabular}{|c|c|c|c|c|}
\hline Enzyme (abbreviation) & Substrate analog & $\begin{array}{l}\text { Acquiring } \\
\text { element }\end{array}$ & Target & Function in ecosystem \\
\hline$\alpha$-Glucosidase (Alph) & 4-MUF- $\alpha$-D-glucoside & Carbon & $\alpha-1,4-$ and $1,6-$ Glucosidic linkages & Starch degradation \\
\hline$\beta$-Glucosidase (Bet) & 4-MUF- $\beta$-D-glucoside & Carbon & $\beta$-1,4-Glucans & Cellulose degradation \\
\hline$\beta$-Xylosidase (Xyl) & 4-MUF- $\beta$-D-xylopyranoide & Carbon & Xylose residues & $\begin{array}{l}\text { Hemicellulose } \\
\text { degradation }\end{array}$ \\
\hline Esterase (Est) & 4-MUF-acetate & Carbon & Small ester containing molecules & Glyceride hydrolization \\
\hline $\begin{array}{l}N \text {-acetyl-glucosamini- } \\
\text { dase (Nac) }\end{array}$ & $\begin{array}{l}\text { 4-MUF- } N \text {-acetyl- } \beta \text {-D- } \\
\text { glucosaminide }\end{array}$ & Nitrogen & $1,4-\beta$-Linkages of glucosamines & Chitin degradation \\
\hline $\begin{array}{l}\text { Leucine aminopeptidase } \\
\text { (Leu) }\end{array}$ & $\begin{array}{l}\text { L-leucine-7-amido-4- } \\
\text { methylcoumarin }\end{array}$ & Nitrogen & $\begin{array}{l}\text { Hydrophobic amino acids from } \mathrm{N} \\
\text { terminus }\end{array}$ & Peptide degradation \\
\hline Endopeptidase (End) & 4-MUF-4-guanadinoenzoate & Nitrogen & Peptide bonds & Peptide degradation \\
\hline Phosphatase (Phos) & 4-MUF-phosphate & Phosphorous & Phosphomono- and diester & $\begin{array}{l}\text { Protein, nucleotide } \\
\text { degradation }\end{array}$ \\
\hline
\end{tabular}

Abbreviation: MUF, methylumbelliferone. 

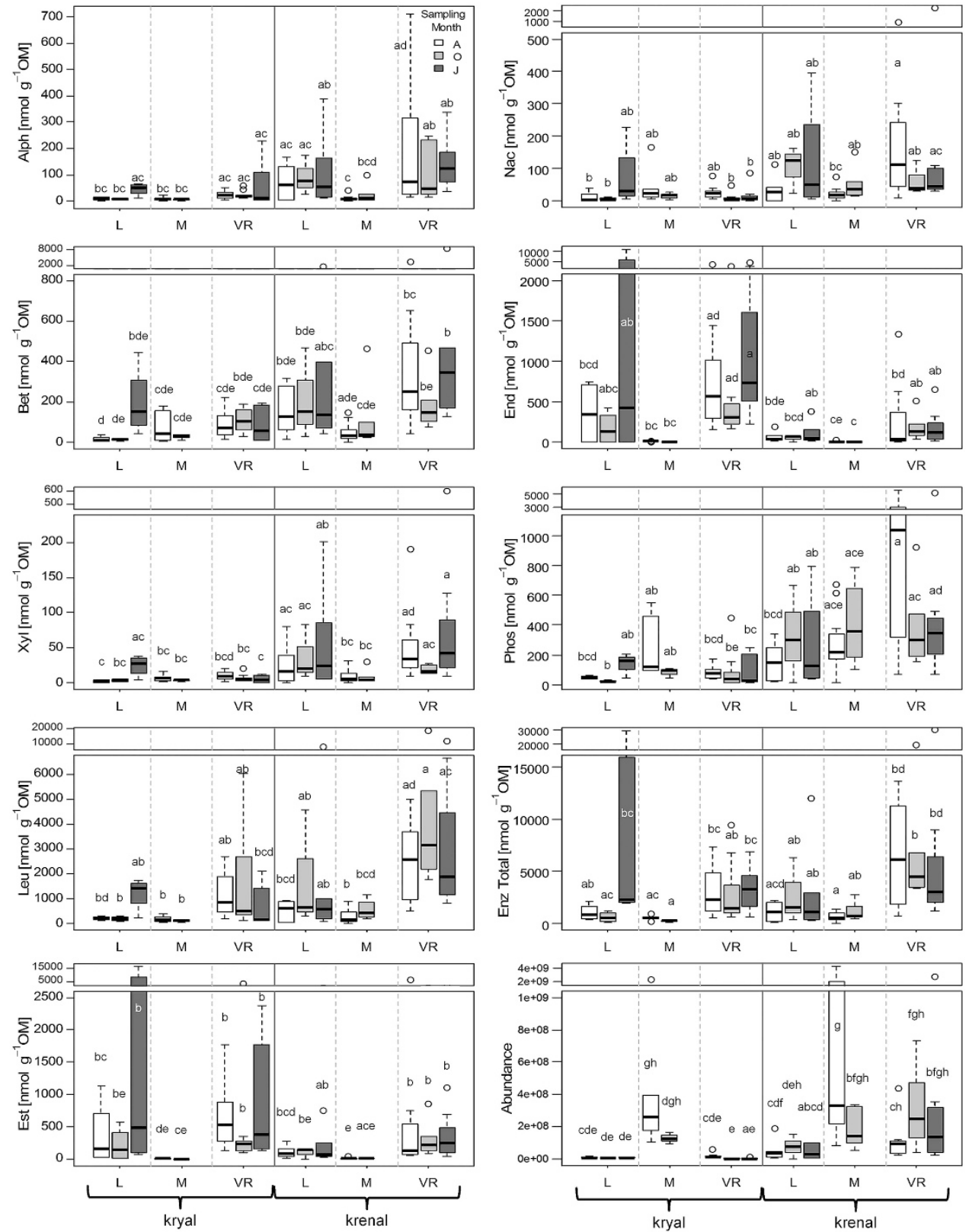

Figure 3 Boxplots of single and total enzymatic activities and cell abundance. Whiskers indicate $1.5 \times$ interquartile range. Groups are split by water source, catchments and sampling dates. Letters show significant differences based on Tukey's honestly significant difference $(P<0.05)$.

catchment and sampling date on physicochemical, community and enzyme activity structure with a full factorial model (Anderson, 2001).

Correlations of single enzymes to physicochemical variables were tested by multiple linear regression. $\mathrm{OM}$ was omitted as an independent variable before analysis to prevent autocorrelation. The models were selected with the Akaike information criterion. Significance of predictors were tested by permutational ANOVA and their relative importance in the linear model was assessed using the lmg metric (Chevan and Sutherland, 1991; Grömping, 2006).

For descriptions of data transformations before the analysis consult the Supplementary
Information. To verify the main patterns seen with the above-mentioned analysis tools, we used additional methods that are described and presented in the Supplementary Information.

\section{Results}

Physicochemical characteristics

The catchments differed significantly in many physicochemical variables, including temperature, sediment $\mathrm{pH}$, conductivity, particulate organic nitrogen and OM (Figure 2). For instance, sediment $\mathrm{pH}$ was different between all catchments, being 
lowest in Macun and highest in Val Roseg, mirroring the geological differences. Significant differences were also found between krenal and kryal systems, for example, there were generally higher temperatures in krenal than kryal systems. Other variables such as conductivity differed only for specific sites or depended on sampling date or catchment, and showed the influence of glacial meltwater during the year and the importance of site positioning along the longitudinal flowpath relative to respective landscape structures. Macun, for instance, showed fewer differences in physicochemical characteristics between water systems because of a decrease in glacial water inputs in the southern subcatchment. Val Roseg, on the other hand, showed the strongest distinction between water systems, that is, $\mathrm{PP}, \mathrm{NH}_{4}$ and $\mathrm{NO}_{2}$ showed higher concentrations in kryal sites because of the overall large glacial water input.

The PERMANOVA revealed an interaction of physicochemical variables with catchments and dates, and catchments and water source, indicating different strengths in temporal fluctuations of physicochemical variables and the separation of the two water systems within each catchment $(P<0.001)$. Again, these findings mirror the actual state of the three catchments concerning their deglaciation and present landscape structures, and thus the present temporal and spatial variability in stream physicochemistry.

\section{Cell abundance}

Bacteria cell abundance in sediments differed between the three catchments $(P<0.001)$ and showed high variability within all catchments. Loetschental had the lowest mean cell densities (range: $2.65 \times 10^{6}-1.90 \times 10^{8}$ cells g $^{-1}$ dry weight, $n=27$ ) followed by Val Roseg (range $1.67 \times 10^{6}$ $2.75 \times 10^{9}$ cells g $^{-1}$ dry weight, $\left.n=51\right)$, and then Macun (range: $5.25 \times 10^{7}-4.44 \times 10^{9}$ cells g $^{-1}$ dry weight, $n=27$ ). Krenal systems had generally higher cell abundances than kryal systems $(P<0.001)$. There was a significant interaction between water source and catchment, with lowest cell abundances in kryal sediments in Loetschental and Val Roseg $(P<0.001$; Figure 3).

\section{Enzymatic activities}

Patterns of enzyme activities varied considerably among sites. ANOVA revealed various significant differences between catchments and water source (Figure 3), whereas temporal effects were generally less pronounced. Highest total potential enzyme activities were found in krenal systems. Comparisons between catchments revealed highest mean values in Roseg, intermediate values in Loetschental and lowest values in Macun $(P<0.05)$.

There was a separation between catchments, water systems and their interactions, with clear separation of the three catchments, and of kryal from krenal sites in Val Roseg and Loetschental (PERMANOVA: $P<0.05$; Figure 4). Macun showed no separation in enzyme patterns between water sources.

Results of multiple linear regression show relationships of single enzymes with water chemistry, sediment characteristics and some nutrient variables (PP and $\mathrm{pH}$ most strongly). Results are summarized in Table 3. The fitted biplot vectors showed the relative physicochemical variables potentially driving the functional separation between water systems (Figure 4). In particular, this approach identified $\mathrm{pH}$, TIC, POC, PP, dissolved phosphorus and $\mathrm{PO}_{4}-\mathrm{P}$ as potential drivers of EF. According to the RDA analysis, $55.8 \%$ of the variation in $\mathrm{EF}$ can be explained by the physicochemical variables. Variation partitioning of separated water sources revealed an equally high contribution of chemical variables for both systems (kryal: 48.0\%; krenal: $47.9 \%$ ), whereas pure physical variables showed no significant influence on EF or were intercorrelated with chemical variables.

Bacterial community structure and linked functions A total of 191 operational taxonomic units (OTUs) were detected across all sites. Ten OTUs were unique to a single site each, whereas 95 OTUs occurred in more than $50 \%$ of all sampled sites. Diversity (Shannon index) was highest in krenal systems $(P<0.001)$.

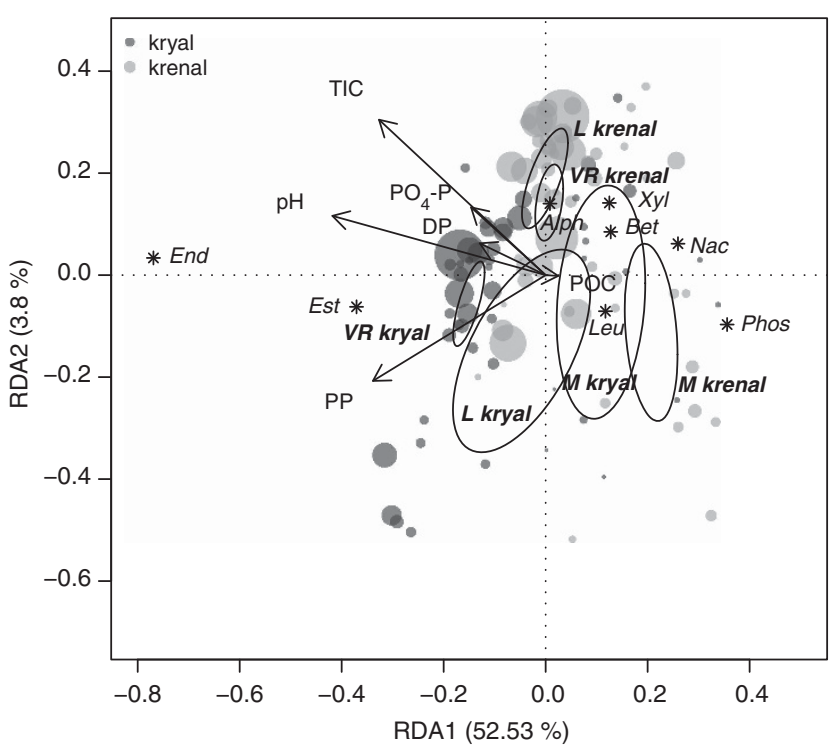

Figure 4 RDA correlation biplot of enzymatic activities. Dots indicate individual sites. The size of dots is relative to the sum of logarithms of all measured enzymes standardized to OM. Dark gray dots correspond to kryal sites and light gray dots to krenal sites. Dispersion ellipses depict the standard error of weighted average scores of catchment groupings (Macun $=\mathrm{M}$; Loetschental =L; Val Roseg=VR; confidence limits=0.95). Environmental variables are fitted as arrows and response variables centroids (enzymes) are depicted with an asterisk. The explained variance for RDA axes 1 and 2 are given. 
Table 3 Relative importance of multiple linear regression of enzymatic activities standardized to OM and physicochemical parameters

\begin{tabular}{|c|c|c|c|c|c|c|c|c|c|c|c|c|c|c|}
\hline \multicolumn{14}{|c|}{ Physicochemical parameters } & \multirow{2}{*}{$\begin{array}{l}\text { Variance } \\
\text { explained by } \\
\text { model }\end{array}$} \\
\hline Enzyme & Temp. & Cond & $p H$ & D90D10 & $D O C$ & $P O C$ & TIC & $\mathrm{NO}_{2}-\mathrm{N}$ & $\mathrm{NO}_{3}-\mathrm{N}$ & $P N$ & $\mathrm{PO}_{4}-\mathrm{P}$ & $D P$ & $P P$ & \\
\hline Alph & 0.025 & & $0.577 * * *$ & 0.021 & & & & $0.112^{*}$ & & $0.039 * *$ & $0.058^{* *}$ & 0.038 & $0.129^{* *}$ & $48.49 \%$ \\
\hline Bet & & & $0.398^{* * *}$ & $0.054^{*}$ & & & & $\overline{0.096}$ & & $0.086^{* * *}$ & $0.089^{* * *}$ & $\overline{0.039}$ & $\overline{0.238} * * *$ & $48.10 \%$ \\
\hline Xyl & $0.099^{*}$ & & $0.308^{* * *}$ & $0.098^{* *}$ & & & & $\overline{0.148} *$ & & $0.063^{* *}$ & $0.111^{* * *}$ & & $\overline{0.173} * * *$ & $41.33 \%$ \\
\hline $\mathrm{Nac}$ & & & $0.091^{* *}$ & $0.098^{*}$ & & & & & & $0.084^{*}$ & $0.076^{*}$ & 0.073 & $\overline{0.578} * * *$ & $26.29 \%$ \\
\hline Est & & & $0.496^{* * *}$ & $0.021^{*}$ & 0.007 & 0.02 & $0.255^{* * *}$ & & 0.009 & & & & $\frac{0.191}{0 . * *}$ & $77.31 \%$ \\
\hline Leu & & 0.182 & $0.525^{* * *}$ & $0.059^{*}$ & & & & $0.061^{*}$ & & $0.055^{* *}$ & $0.024^{*}$ & & $0.095^{* * *}$ & $45.08 \%$ \\
\hline End & & & $0.353^{*}$ & & 0.009 & $0.032^{* * *}$ & $0.524 * * *$ & $\overline{0.128} *$ & 0.014 & $0.017^{*}$ & & & $\overline{0.275} * * *$ & $76.69 \%$ \\
\hline Phos & 0.106 & $0.077^{*}$ & $0.058^{*}$ & $0.128^{* *}$ & & $\overline{0.053} *$ & 0.082 & 0.198 & & & & & $0.297 * *$ & $40.58 \%$ \\
\hline
\end{tabular}

Abbreviations: AIC, Akaike information criterion; Alph, $\alpha$-glucosidase; Bet, $\beta$-glucosidase; End, endopeptidase; Est, esterase; DOC, dissolved organic matter; DP, dissolved phosphorus; Leu, leucine aminopeptidase; Nac, $N$-acetyl-glucosaminidase; $\mathrm{NO}_{2}-\mathrm{N}$, nitrite; $\mathrm{NO}_{3}-\mathrm{N}$, nitrate; $\mathrm{OM}_{\text {, }}$ organic matter; Phos, phosphatase; PN, particulate organic nitrogen; $\mathrm{POC}$, particulate organic carbon; $\mathrm{PO}_{4}-\mathrm{P}$, phosphate; $\mathrm{PP}$, particulate phosphorus; TIC, total inorganic carbon; Xyl, $\beta$-xylosidase.

${ }^{*} P<0.05$.

${ }^{* *} P<0.01$.

$* * * P<0.001$.

Underlined values are contributing negatively to the distinct enzyme activity. Values are scaled to $100 \%$ of the explained variance, and models were selected with AIC.

RDA differentiated BCC between catchments and water sources (Figure 5). BCC were similar in Loetschental and Val Roseg in the krenal sediments. Macun was more separated from the other two catchments and showed a less pronounced separation of kryal and krenal sites compared with Val Roseg (Figure 5). Krenal systems in Val Roseg showed no temporal pattern compared with the temporal shift in BCC in kryal sites in Val Roseg ( $P=0.96$ and $P<0.001$, respectively). Temporal BCC changes were not significant in Loetschental krenal and kryal sites $(P>0.05)$. Macun BCC showed no temporal pattern in kryal sites but did in krenal sites ( $P=0.79$ and $P<0.05$, respectively).

Biplots showed which chemical variables correlated with trends in the BCC distinguishing kryal and krenal systems. High values in nutrient and carbon variables were generally associated with kryal systems. In particular, gradients in sediment $\mathrm{pH}$ seemed to be of high importance for driving community composition (Figure 5). The importance of glacial ablation in August is mirrored by high PP and $\mathrm{NO}_{2}-\mathrm{N}$. High temperature and $\mathrm{OM}$ appeared correlated with krenal community composition. RDA revealed that $19.9 \%$ of the total variation was explained by forward-selected environmental variables. Variation partitioning of physical and chemical variables applied only to kryal systems showed that $23.2 \%$ of the variation in community structure could be accounted for by water chemistry. Krenal systems, in contrast, had just $10.9 \%$ of the variation explained by water chemistry, reflecting their more stable environmental conditions.

Relating enzyme activity patterns to BCC by means of Mantel tests showed differences in the strength of association, with a maximum correlation for Val Roseg $(0.561, P<0.01)$, intermediate

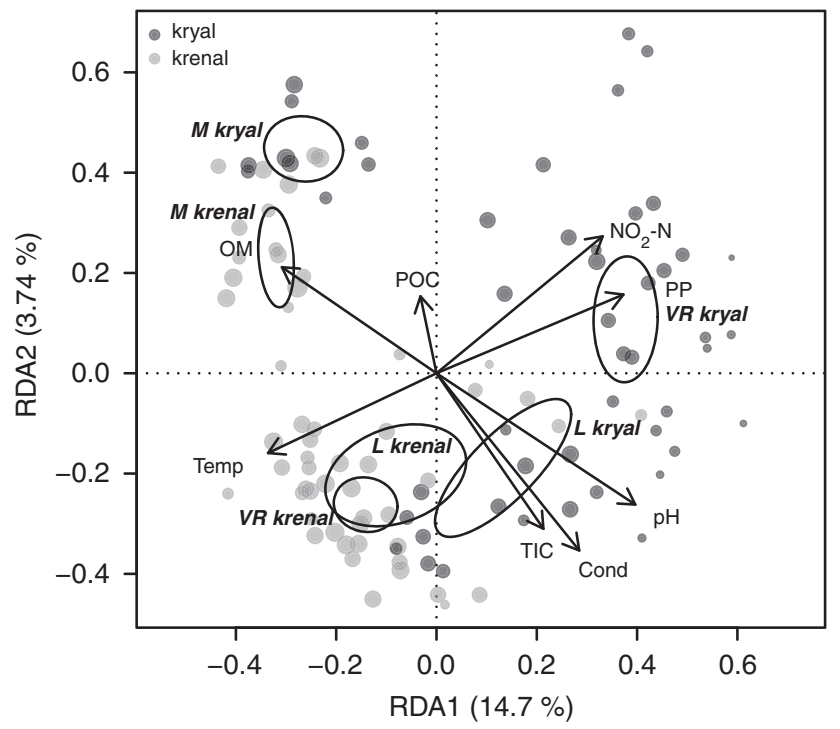

Figure 5 RDA correlation biplot of ARISA profiles. Dots indicate individual sites. The size of dots is relative to the numbers of OTUs at a site. Dark gray dots correspond to kryal sites and light gray dots to krenal sites. Dispersion ellipses depict the standard error of weighted average scores of catchment groupings (Macun $=\mathrm{M}$; Loetschental $=\mathrm{L}$; Val Roseg =VR; confidence limits $=0.95$ ). Environmental variables are fitted as arrows. The explained variance for RDA axes 1 and 2 are given.

correlation for Loetschental $(0.389, P<0.01)$ and nonsignificant correlation for Macun.

\section{Discussion}

Our results showed a strong influence of water source on BCC, EF and spatiotemporal dynamics of bacterial assemblages within hyporheic sediments of streams in glaciated alpine floodplains. Although 
the study catchments showed distinct patterns in BCC, EF and temporal dynamics, water source influenced heterotrophic bacteria occurrence, functioning or both in all catchments. Finding larger and more tightly linked temporal shifts in BCC and $\mathrm{EF}$ in kryal systems in Val Roseg mirrored their higher temporal heterogeneity in physical and chemical characteristics and supported our hypothesis that typical kryal BCC are dominated by generalists. Although temporal dynamics in BCC were not as apparent within krenal sites, there still was a remarkable difference in BCC and EF between catchments.

The patterns we observed appeared to follow a hierarchical template: geological differences such as sediment $\mathrm{pH}$ or conductivity had a strong influence and acted as a principal separator of bacterial community structure and enzymatic expression patterns between catchments. Fierer and Jackson (2006) compared soil samples across North and South America and found that soil $\mathrm{pH}$ was the best predictor of bacterial community composition and richness. Landscape features such as glaciers have the potential to create strong landscape heterogeneity by dictating coarse-scale physicochemical characteristics of habitats over time and space. Hydrogeochemical conditions, disturbance as well as spatial connectivity between aquatic systems can be altered by glaciers, and it has been shown that these mechanisms can influence BCC (Sekar et al., 2002; Frey et al., 2009; Langenheder et al., 2011). In contrast, lake outlet streams or groundwater-fed streams provide more spatiotemporal stability and a more homogeneous landscape (Tockner et al., 1997; Brown et al., 2003), and the smaller fluctuations in physicochemical characteristics in such habitats cause reduced variability in bacterial communities.

Glaciers and lakes: landscape features that drive hydrology and bacterial communities

Seasonal glacial melt-water dynamics have a major influence on a suite of floodplain characteristics and therefore have a strong role in the ecology of alpine streams. Summer ablation leads to distinct physicochemical water characteristics, increased sediment load, decreased channel stability and a greater hydrological linkage between aquatic and terrestrial compartments (Milner and Petts, 1994; Ward, 1994; Tockner et al., 1997; Brown et al., 2003; Battin et al., 2004). PP was an important driver for a whole set of enzymes and equalized EF over a large spatial scale. Altered activities owing to phosphorous amendments have been observed before in other systems such as Mediterranean rivers or several types of soils (Romaní et al., 2004; DeForest et al., 2012). Phosphorus availability also can be decreased with sediment $\mathrm{pH}$ and is strongly dependent on the parent material, weathering and glacial-mediated scouring of the bed rock (Robarge, 2008). Similarly $\mathrm{PO}_{4}-\mathrm{P}$, dissolved phosphorus, $\mathrm{POC}, \mathrm{NH}_{4}-\mathrm{N}$ and temperature influenced EF and BCC, typically distinguishing krenal from kryal systems during summer ablation and being strong delineators for BCC and EF. The degree of deglaciation thus influences, in concert with geological factors, EF and BCC characteristics within a landscape because of its impact on the physicochemical properties of a habitat patch (i.e. within a subcatchment or reach along the flow path). Indeed, the Loetschental subcatchment fed by the Jegi glacier has a physicochemical characteristic resembling krenal systems, indicating a reduced glacial water input and consequently an EF and BCC characteristic that is more congruent with that of a krenal system.

The fact that Macun EF did not differ between water sources can be related to mitigated glacial water input by lakes, essentially homogenizing the two water systems. Kryal streams in Macun had no affiliation in either BCC or EF with kryal streams in the other two catchments. Patterns in benthic biofilms having lower bacterial abundance in kryal channels, as occurring in Val Roseg and Loetschental, also were not present within this catchment (e.g. Battin et al., 2004). As a mitigating agent of physical and chemical disturbance, lakes can act as sinks of glacial-induced high sediment loads, consequently reducing $\mathrm{PP}$ concentrations at the lake outlet. As PP was shown to be an important driver for EF and BCC, the presence of lakes may thus partially offset the differences between stream types in the Macun catchment. Phosphorous availability can additionally be reduced by the low sediment $\mathrm{pH}$ further separating $\mathrm{EF}$ and BCC from the other two catchments.

\section{Different habitat, different strategy}

The linkage of species composition and EF appears to be a continuum extending from functional plasticity and redundancy to a complete coupling, depending on the investigated functions, the complexity of the system and the players involved (Langenheder et al., 2006; Boucher and Debroas, 2009; Comte and Del Giorgio, 2010). The results of this study showed that the coupling between bacteria structure and function can be stronger or weaker depending on environmental constraints that determine local community structure. Temporal shifts in BCC and EF in kryal channels were linked to shifting physicochemical templates as shown by the large fraction of variance explained by physicochemical variables and the broader fluctuations in the physicochemical template within kryal systems. Variation partitioning only explained a small part of BCC dynamics in krenal systems via the influence of chemical and physical variables or their interactions.

Enzymatic functions, however, were influenced to the same extent by physicochemical variables in kryal as in krenal systems, indicating a large functional plasticity in both types of systems. The underlying mechanisms leading to this systemic EF 
plasticity differ between the typical kryal and krenal water systems. Krenal bacterial communities probably withstand environmental changes by adapting their single-cell metabolism, whereas kryal communities lacking this plasticity shift towards a community composition dominated by specialists able to perform a specific EF under the given conditions. The lower Shannon diversity index in kryal systems may also be interpreted as a result of a dominance of a few specialists adapted to the current set of environmental conditions.

\section{Implications of global change for alpine stream microbiomes}

Glaciers continue to recede and the future loss of snow and ice will alter alpine ecosystems in fundamental ways. It is expected that there will be a strong decrease in glacial meltwater input to alpine floodplains, altering spatial and temporal runoff dynamics. In general, a shift towards a more groundwater-dominated landscape is likely to occur in the near future in most alpine areas. This change in water source also entails a shift in the physicochemical and structural habitat templates. General differences between kryal and krenal sediment types have been shown before (Logue et al., 2004), but the findings of this study show that microbial communities are adapted to habitat-specific physicochemical conditions defined by their community metabolic capabilities. Global change induced shifts in water sources are therefore expected to result in a shift in both microbial communities and mediated ecosystem services.

Temperature in kryal channels will increase in the future, whereas PP will decrease (Milner et al., 2009). As water temperature and $P P$ were correlated with BCC, a loss of diversity because of a narrower bandwidth and less fluctuation could be expected. This change is even more likely when resident kryal specialists must compete with invading krenal generalists in an environment becoming more suitable for the latter. Although we did not see a lower overall OTU richness in kryal systems, a future shift towards a more even community structure and loss of specialists could be caused by decreased glacial runoff in kryal systems. This shift in water source would lead to a reduced temporal and spatial turnover of microbial species, and decreased beta diversity at the landscape scale. As environmental complexity is linked to biodiversity and ecosystem functioning, an impact on water properties can be expected when landscape heterogeneity and biodiversity are reduced (Langenheder et al., 2010).

Changes in vegetation in alpine landscapes that occur in concert with glacial retreat can alter carbon inputs substantially (Theurillat and Guisan, 2001). As OM, POC and TIC influenced BCC, there will be an impact on krenal microbial communities. OM originates from benthic algal inputs that grow well within krenal systems. In-stream primary production could become more important in the future for kryal systems, thus fueling hyporheic sediments with OM and thus promoting a shift towards a krenal BCC characteristic (Logue et al., 2004; Uehlinger et al., 2010).

Total cell abundance is also expected to change in alpine stream sediments. The quantity and quality of OM has been shown to correlate with shifts in BCC and bacterial abundance (Crump et al., 2003; Olapade and Leff, 2005, 2006). Physical changes in the habitat template such as increasing channel stability because of reduced discharge may additionally favor generalists and reduce stochastic proliferations as apparent in kryal channels (Milner et al., 2009). For instance, Füreder (2007) proposed an increasing importance of macroinvertebrate generalists within kryal systems because of reduced glacial runoff.

An altered physicochemical habitat template is likely to influence EF in both water systems. As BCC are more stable within krenal systems and they maintain a high functional plasticity, we would expect to see a less pronounced shift in community composition and a longer time horizon until changes appear. In contrast, kryal system BCC could change more rapidly and be more pronounced. They seem to be more constrained by physicochemical variables because of a reduced functional plasticity, and thus are forced to restructure their community with the changing habitat template. A reciprocal transplant experiment of krenal and kryal sediment types previously conducted in the Val Roseg showed that after 21 days of incubation in the non-native water source, there still was the signature of the native communities apparent with a generally smaller shift in BCC in krenal sediments (Freimann et al., 2013). EF, on the other hand, adapted relatively fast to the new environment in both sediment types. The apparent situation in Macun is likely to represent such a state, where communities adapt their EF to the reduced glacial water inputs, whereas BCC still show a historical imprint. Regardless of shifts in BCC, EF could experience a significant change with reduced or lost kryal water inputs.

Distinct enzymes correlated well with physicochemical characteristics and BCC of each system. Increased ester and endopeptidase activity characterized kryal sediments, whereas $\alpha$-glucosidase, $\beta$-glucosidase, $\beta$-xylosidase, $N$-acetyl-glucosaminidase, leucine aminopeptidase and phosphatase were more expressed in krenal systems. The importance of these typical krenal enzymes has been described for lowland rivers in both the water column and sediments (Wilczek et al., 2005) and mirrors the importance of gathering carbon, nitrogen and phosphorous from different sources. For instance, krenal systems have high carbon input via cellulose, thus expressing Bet becomes important within krenal sediments to gather carbon from this non-limiting resource (Zah and Uehlinger, 2001). In kryal 
systems, ester and endopeptidase seem to be favored to gather carbon and nitrogen, that is, from estercontaining molecules such as lipids and from peptides. Phosphorus seems to be a limiting resource in krenal systems, thus investment in phosphatase is favored compared with kryal systems that experience high PP loads that may be partly bioavailable (Hodson et al., 2004). Decreased concentrations of PP could rapidly promote a functional shift towards krenal characteristics or lead to generally higher enzymatic activity. Specific enzymes that correlate well with physicochemical characteristics of kryal water could become less expressed, whereas typical krenal enzymes would dominate EF.

Our study shows how lotic microbial structure and function in glaciated alpine floodplains will potentially change as a consequence of altered hydrological conditions in the context of apparent landscape structures. Functional flexibility was high in both water systems, but it is unclear to what extent a shift of kryal BCC would be buffered if their provided EF could completely adapt to a changed physicochemical environment. Even if a functional response lag and high redundancy prevents microbial functionality from collapse, there still will be consequences for carbon and nitrogen cycles at the larger scale, that is, historical legacies altering EF (Strickland et al., 2009; Shen and He, 2011). As microbes have an important role linking geochemical organic matter, nutrient cycling and higher trophic levels, a significant shift in alpine floodplain foodwebs and EF can also be expected. Longterm studies in these environments would give an opportunity to examine how persistent (kryal) bacterial communities are when substantial changes in habitat templates occur and how ecosystem functionality adapts or collapses. Predicting future EF and their impact on biogeochemical cycling should consider functional flexibility of apparent BCC as they can react differently to altered alpine ecosystems.

\section{Conflict of Interest}

The authors declare no conflict of interest.

\section{Acknowledgements}

We thank the Swiss National Park for access rights to the Macun catchment, Simone Blaser and Christa Jolidon for field and laboratory assistance and the anonymous reviewers for their valuable comments and suggestions to improve the quality of the paper. This study was funded by the Swiss National Foundation (No. 31003A-119735).

\section{References}

Acuna V, Wolf A, Uehlinger U, Tockner K. (2008). Temperature dependence of stream benthic respiration in an alpine river network under global warming. Freshwat Biol 53: 2076-2088.

Allison SD, Martiny JBH. (2008). Resistance, resilience, and redundancy in microbial communities. Proc Natl Acad Sci USA 105: 11512-11519.

Anderson MJ. (2001). A new method for non-parametric multivariate analysis of variance. Austral Ecol 26: 32-46.

Arpigny JL, Jaeger KE. (1999). Bacterial lipolytic enzymes: classification and properties. Biochem J 343: 177-183.

BAFU (2010). BAFU Annual Report. Federal Office for the Environment (FOEN): Geneva, Switzerland.

Battin TJ. (1999). Hydrologic flow paths control dissolved organic carbon fluxes and metabolism in an alpine stream hyporheic zone. Water Resour Res 35: 3159-3169.

Battin TJ, Wille A, Psenner R, Richter A. (2004). Large-scale environmental controls on microbial biofilms in high-alpine streams. Biogeosciences 1: 159-171.

Blanchet FG, Legendre P, Borcard D. (2008). Forward selection of explanatory variables. Ecology 89: 2623-2632.

Boucher D, Debroas D. (2009). Impact of environmental factors on couplings between bacterial community composition and ectoenzymatic activities in a lacustrine ecosystem. FEMS Microbiol Ecol 70: 66-78.

Boyer EW, Hornberger GM, Bencala KE, Mcknight DM. (1997). Response characteristics of doc flushing in an alpine catchment. Hydrol Process 11: 1635-1647.

Brown GH, Fuge R. (1998). Trace element chemistry of glacial meltwaters in an alpine headwater catchment. In: Kovar K (ed) Hydrology, Water Resources and Ecology in Headwaters. IAHS Press: Wallingford, pp 435-442.

Brown LE, Hannah DM, Milner AM. (2003). Alpine stream habitat classification: An alternative approach incorporating the role of dynamic water source contributions. Arct Antarct Alp Res 35: 313-322.

Bürgmann H, Jenni S, Vazquez F, Udert KM. (2011). Regime shift and microbial dynamics in a sequencing batch reactor for nitrification and anammox treatment of urine. Appl Environ Microbiol 77: 5897-5907.

Chevan A, Sutherland M. (1991). Hierarchical partitioning. Am Stat 45: 90-96.

Comte J, Del Giorgio PA. (2010). Linking the patterns of change in composition and function in bacterioplankton successions along environmental gradients. Ecology 91: 1466-1476.

Comte J, Del Giorgio PA. (2011). Composition influences the pathway but not the outcome of the metabolic response of bacterioplankton to resource shifts. PLoS One 6: e25266.

Crump BC, Kling GW, Bahr M, Hobbie JE. (2003). Bacterioplankton community shifts in an arctic lake correlate with seasonal changes in organic matter source. Appl Environ Microbiol 69: 2253-2268.

Deforest JL, Smemo KA, Burke DJ, Elliott HL, Becker JC. (2012). Soil microbial responses to elevated phosphorus and $\mathrm{pH}$ in acidic temperate deciduous forests. Biogeochemistry 109: 189-202.

Edwards RT, Meyer JL, Findlay SEG. (1990). The relative contribution of benthic and suspended bacteria to system biomass, production, and metabolism in a low-gradient blackwater river. J N Am Benthol Soc 9: 216-228.

Fierer N, Jackson RB. (2006). The diversity and biogeography of soil bacterial communities. Proc Natl Acad Sci USA 103: 626-631. 
Findlay S. (1995). Importance of surface-subsurface exchange in stream ecosystems: the hyperheic zone. Limnol Oceanogr 40: 159-164.

Findlay S, Quinn JM, Hickey CW, Burrell G, Downes M. (2001). Effects of land use and riparian flowpath on delivery of dissolved organic carbon to streams. Limnol Oceanogr 46: 345-355.

Findlay S, Sinsabaugh RL. (1999). Unravelling the sources and bioavailability of dissolved organic matter in lotic aquatic ecosystems. Mar Freshwat Res 50: 781-790.

Freimann R, Bürgmann H, Findlay SEG, Robinson CT. (2013). Response of lotic microbial communities to altered water source and nutritional state in a glaciated alpine floodplain. Limnol Oceanogr 58: 951-965.

Frey B, Kremer J, Rüdt A, Sciacca S, Matthies D, Lüscher P. (2009). Compaction of forest soils with heavy logging machinery affects soil bacterial community structure. Eur J Soil Biol 45: 312-320.

Füreder L. (2007). Life at the edge: habitat condition and bottom fauna of alpine running waters. Int Rev Hydrobiol 92: 491-513.

Grömping U. (2006). Relative importance for linear regression in R: the package relaimpo. I Stat Softw 17: $1-27$.

Hall MHP, Fagre DB. (2003). Modeled climate-induced glacier change in glacier national park, 1850-2100. Bioscience 53: 131-140.

Hall RO, Meyer JL. (1998). The trophic significance of bacteria in a detritus-based stream food web. Ecology 79: 1995-2012.

Hendricks SP. (1993). Microbial ecology of the hyporheic zone: a perspective integrating hydrology and biology. J N Am Benthol Soc 12: 70-78.

Hodson A, Mumford P, Lister D. (2004). Suspended sediment and phosphorous in proglacial rivers: bioavailability and potential impacts upon the $\mathrm{p}$ status of ice-marginal receiving waters. Hydrol Process 18: 2409-2422.

Horton P, Schaefli B, Mezghani A, Hingray B, Musy A. (2006). Assessment of climate-change impacts on alpine discharge regimes with climate model uncertainty. Hydrol Process 20: 2091-2109.

IPCC (2007). Climate change 2007: the physical science basis. In: Solomon S, Qin D, Manning M, Chen Z, Marquis M, Averyt KB et al. (eds) Contribution of Working Group I to the Fourth Assessment Report of the Intergovernmental Panel on Climate Change. Press CU: New York, NY, USA.

Kirchman DL. (1994). The uptake of inorganic nutrients by heterotrophic bacteria. Microb Ecol 28: 255-271.

Labhart TP. (1998). Geology of Switzerland.:Ott Verlag: Thun, Switzerland.

Langenheder S, Berga M, Östman O, Székely AJ. (2011). Temporal variation of $\beta$-diversity and assembly mechanisms in a bacterial metacommunity. ISME J 6: 1107-1114.

Langenheder S, Bulling MT, Solan M, Prosser JI. (2010). Bacterial biodiversity-ecosystem functioning relations are modified by environmental complexity. PLoS One 5: e10834.

Langenheder S, Lindström ES, Tranvik LJ. (2006). Structure and function of bacterial communities emerging from different sources under identical conditions. Appl Environ Microbiol 72: 212-220.

Logue JB, Robinson CT, Meier C, Van Der Meer JR. (2004). Relationship between sediment organic matter, bacteria composition, and the ecosystem metabolism of alpine streams. Limnol Oceanogr 49: 2001-2010.

Maisch M. (1988). The movements of glaciers and snow-lines since the 1850 advance in the canton of Graubunden, Switzerland. Die Veraenderungen der Gletscherflaechen und Schneegrenzen seit dem Hoechstand von 1850 im Kanton Graubunden (Schweiz) 70: 113-130.

Makoi JHJR, Ndakidemi PA. (2008). Selected soil enzymes: examples of their potential roles in the ecosystem. Afr J Biotechnol 7: 181-191.

Malard F, Tockner K, Ward JV. (1999). Shifting dominance of subcatchment water sources and flow paths in a glacial floodplain, Val Roseg, Switzerland. Arct Antarct Alp Res 31: 135-150.

Malard F, Tockner K, Ward JV. (2000). Physico-chemical heterogeneity in a glacial riverscape. Landscape Ecol 15: $679-695$.

Mantel N. (1967). The detection of disease clustering and a generalized regression approach. Cancer Res 27: 209-220.

Milner AM, Brown LE, Hannah DM. (2009). Hydroecological response of river systems to shrinking glaciers. Hydrol Process 23: 62-77.

Milner AM, Petts. GE. (1994). Glacial rivers: physical habitat and ecology. Freshwat Biol 32: 295-307.

Oksanen J, Blanchet FG, Kindt R, Legendre P, O'hara RB, Simpson GL et al. (2011). Vegan: Community ecology, r package version 1: 17-6. http://cran.R-project.Org/ package=vegan.

Olapade OA, Leff LG. (2005). Seasonal response of stream biofilm communities to dissolved organic matter and nutrient enrichments. Appl Environ Microbiol 71: 2278-2287.

Olapade OA, Leff LG. (2006). Influence of dissolved organic matter and inorganic nutrients on the biofilm bacterial community on artificial substrates in a northeastern Ohio, USA, stream. Can J Microbiol 52: 540-549.

Peres-Neto PR, Legendre P, Dray S, Borcard D. (2006). Variation partitioning of species data matrices: estimation and comparison of fractions. Ecology 87: 2614-2625.

Pernthaler J, Glöckner FO, Schönhuber W, Amann R. (2001). Fluorescence in situ hybridization (FISH) with rRNA-targeted oligonucleotide probes. In: Paul JH (ed.) Methods in Microbiology. Academic Press: New York, NY, pp 207-226.

Porter KG, Feig YS. (1980). The use of dapi for identifying and counting aquatic microflora. Limnol Oceanogr 25: 943-948.

$\mathrm{R}$ development core team (2012). $R$ : A language and environment for statistical computing. $R$ foundation for statistical computing. $\mathrm{R}$ development core team: Vienna, Austria. http://www.R-project.org/.

Robarge W. (2008). Acidity. In: Chesworth W (ed.) Encyclopedia of Soil Science. Springer: Netherlands, pp 10-21.

Robinson CT, Hieber M, Wenzelides V, Lods-Crozet B. (2007). Macroinvertebrate assemblages of a high elevation stream/lake network with an emphasis on the chironomidae. Fundam Appl Limnol 169: 25-36.

Robinson CT, Kawecka B. (2005). Benthic diatoms of an alpine stream/lake network in Switzerland. Aquat Sci 67: 492-506. 
Robinson CT, Matthaei S. (2007). Hydrological heterogeneity of an alpine stream-lake network in Switzerland. Hydrol Process 21: 3146-3154.

Romaní AM, Giorgi A, Acuña V, Sabater S. (2004). The influence of substratum type and nutrient supply on biofilm organic matter utilization in streams. Limnol Oceanogr 49: 1713-1721.

Schofield RK, Taylor AW. (1955). The measurement of soil pH. Soil Sci Soc Am J 19: 164-167.

Schmidt S, Weber B, Winiger M. (2009). Analyses of seasonal snow disappearance in an alpine valley from micro- to meso-scale (Loetschental, Switzerland). Hydrol Process 23: 1041-1051.

Sekar R, Nair KVK, Rao VNR, Venugopalan VP. (2002). Nutrient dynamics and successional changes in a lentic freshwater biofilm. Freshwat Biol 47: 1893-1907.

Selinummi J, Seppälä J, Yli-Harja O, Puhakka JA. (2005). Software for quantification of labeled bacteria from digital microscope images by automated image analysis. Biotechniques 39: 859-862.

Shen J, He J. (2011). Responses of microbes-mediated carbon and nitrogen cycles to global climate change. Acta Ecol Sin 31: 2957-2967.

Simon J, Blott KP. (2001). Gradistat: a grain size distribution and statistics package for the analysis of unconsolidated sediments. ESPL 26: 1237-1248.

Sinsabaugh RL, Antibus RK, Linkins AE. (1991). An enzymic approach to the analysis of microbial activity during plant litter decomposition. Agric Ecosyst Environ 34: 43-54.

Sinsabaugh RL, Lauber CL, Weintraub MN, Ahmed B, Allison SD, Crenshaw C et al. (2008). Stoichiometry of soil enzyme activity at global scale. Ecol Lett 11: 1252-1264.

Smith BPG, Hannah DM, Gurnell AM, Petts GE. (2001). A hydrogeomorphological context for ecological research on alpine glacial rivers. Freshwat Biol 46: 1579-1596.

Stanford JA, Ward JV. (1993). An ecosystem perspective of alluvial rivers: connectivity and the hyporheic corridor. J N Am Benthol Soc 12: 48-60.
Strickland MS, Lauber C, Fierer N, Bradford MA. (2009). Testing the functional significance of microbial community composition. Ecology 90: 441-451.

Swiss climate change scenarios CH2011 (2011). C2SM M, ETH Zurich. NCCR Climate, OcCC (publishers): Zurich.

Theurillat JP, Guisan A. (2001). Potential impact of climate change on vegetation in the european alps: a review. Clim Change 50: 77-109.

Tockner K, Malard F, Burgherr P, Robinson CT, Uehlinger U, Zah $\mathrm{R}$ et al. (1997). Physico-chemical characterization of channel types in a glacial floodplain ecosystem (Val Roseg, Switzerland). Arch Hydrobiol 140: 433-463.

Tockner K, Malard F, Uehlinger U, Ward JV. (2002). Nutrients and organic matter in a glacial riverfloodplain system (Val Roseg, Switzerland). Limnol Oceanogr 47: 266-277.

Uehlinger U, Robinson CT, Hieber M, Zah R. (2010). The physico-chemical habitat template for periphyton in alpine glacial streams under a changing climate. Hydrobiologia 657: 107-121.

Vihinen M, Mäntsälä P. (1989). Microbial amylolytic enzymes. Crit Rev Biochem Mol Biol 24: 329-418.

Ward JV. (1994). Ecology of alpine streams. Freshwat Biol 32: $277-294$.

Wilczek S, Fischer H, Pusch MT. (2005). Regulation and seasonal dynamics of extracellular enzyme activities in the sediments of a large lowland river. Microb Ecol 50: 253-267.

Wood SN. (2006). Generalized Additive Models: An Introduction with $R$. Chapman \& Hall: Boca Raton, FL, USA.

Yannarell AC, Kent AD, Lauster GH, Kratz TK, Triplett EW. (2003). Temporal patterns in bacterial communities in three temperate lakes of different trophic status. Microb Ecol 46: 391-405.

Zah R, Uehlinger U. (2001). Particulate organic matter inputs to a glacial stream ecosystem in the swiss alps. Freshwat Biol 46: 1597-1608.

Zemp M, Haeberli W, Hoelzle M, Paul F. (2006). Alpine glaciers to disappear within decades? Geophys Res Lett 33: L13504.

Supplementary Information accompanies this paper on The ISME Journal website (http://www.nature.com/ismej) 